I Tisparia, LVII/3, núm. 200 (1 (1)

\title{
EL ADOPCIONISMO Y LAS EVOLUCIONES RELIGIOSAS Y POLÎTICAS EN EL REINO ASTUR
}

pot

\author{
AMANCIO ISLA FREZ \\ Universitat Rovira i Virgili. Tarragona.
}

RESUMEN: La controversia adopcionista se presenta en su entorno astur, destacando su continuidad desde Beato de Liébana y a lo largo del reinado de Alfonso II. Fuentes de este periodo pueden entenderse desde la perspectiva del conflicto religioso. Las cambios politicos de aquellas décadas se explican como parte de una politica de decidida apertura a otras realidades, religiosas y políticas, distinlas de las visigodas.

PALABRAS ClAVE: Adopcionismo. Reino astur. Carolingios. Temprana Edad Media. España.

ABSTRACT: The adoptionist controversy is presented in its Asturian framework, underlining its continuity from Beatus of Liébana to the reign of Alphonse II. Sources of this period can be understood within the religious conflict. The political changes of those decades are explained as part of a policy of opening up to other realities, religious and political, different from the Visigotbic.

KEY wORDS: Adoptionism. Astur Kingdom. Carolingians. Early Medieval History. Spain.

Diversas publicaciones han venido apareciendo estos años en relación con el adopcionismo, es decir, con el conflicto cristológico que sacudió el Occidente cristiano poco antes del 800. En aquella polémica participaron el metropolitano de Toledo Elipando y Beato, monje lebaniego '. De éste sabemos que

1 Obras completas, ed. González Echegaray, A. del Campo y L.G. Freeman, Madrid, 1995. Con esta edición bilingüe se obtiene un acceso cómodo a las obras de Beato. Acompañan a esta publicación unos prólogos. Su vida y trayectoria es recogida en uno de carácter histórico, que cumple con su propósito de ser breve introducción al tiempo y la obra de Beato de Liébana. Mientras que la referencia a la polémica adopcionista figura en otro (67\%ss), más descuidado. Resulta grave que aún se presente a Elipando como un torturador y falseador de citas de autoridades patrísticas y de la liturgia (p. 682), argumento ya utilizado por Menéndez Pelayo (Historia de los beterodoxos españoles, II, Madrid, 1917, 305), criticado por Abadal y discutible a la luz de la

Hispania, LVIII/3, núm. 200 (1998) 971-993 
fue presbítero, curiosamente ni Elipando, ni Alvaro de Córdoba después, ni él mismo afirman su condición de abad, que sólo es sostenida por el distante Alcuino de York, quizás porque el lebaniego sólo alcanzó esta dignidad más tarde. También estuvieron involucrados Félix, obispo de Urgell; Alcuino de York, afincado en el entorno de Carlomagno; el papa Adriano y otros personajes, algunos de los cuales sólo conocemos de nombre.

El libro de Cavadini ${ }^{2}$ es una aportación muy relevante al estudio del adopcionismo. Se enfrenta a la versión, a menudo presente en obras generales, que supone el adopcionismo una polémica de escaso nivel que reflejaría un supuesto deterioro de la teología occidental. Cavadini pretende mostrar lo contratio, la capacidad de un grupo de teólogos para presentar propuestas y discutirlas dentro de un alto grado de especialización, poniendo de relieve la importancia de la cultura teológica de los mismos.

Su obra resalta el punto de partida en buena medida semejante de Elipando de Toledo y Beato de Liébana. Se trata de la tradición cristológica occidental. Quizás aquí podría haberse destacado cuánto la tradición teológica hispana debía a su enfrentamiento y discusión con las propuestas provenientes del Imperio e, incluso, las romanas, pues de hecho la teología surgida en el reino godo ha de entenderse en buena medida como réplica, como diálogo crítico a las venidas de Oriente.

También critica la impresión de que el adopcionismo tenga que ver con una adecuación al Islam, propugnada por Rivera Recio, quien llega a ver en Elipando una formación nestoriana que relaciona con miembros de esta secta que habrían llegado con los invasores musulmanes ${ }^{3}$.

Cavadini subraya que la cristología de Elipando no era nestoriana y que siempre mantuvo con claridad la doble naturaleza y la unidad de persona - lo que, por otra parte, también sostuvo Nestorio-. La cuestión fundamental era la articulación de la naturaleza humana en Cristo y cómo se definía la deitate exinanita por la que el Verbo se hacía carne. Elipando, inmerso en la tradición cris-

edición de J. GIL (Corpus scriptorum Muzarabicorum, I, Madrid, 1973). Faltan además referencias bibliográficas como la de Abadal (La batalla del adopcionismo en la desintegración de la Iglesia visigoda, Batcelona, 1949), siendo la apoyatura básica Rivera Recio. La obra de Abadal es todavía fundamental para estas cuestiones. Vid también, VÁzQUEZ DE PARGA, «Beato y el ambiente cultural de su épocas en Actas del Simposio para el estudio de los códices del 'Comentario al Apocalipsis' de Beato de Liébana, Madrid, 1978, 35ss; M.I. LoRING, Cantabria en la Alta Edad Media organización eclesiástica y relaciones sociales, Madrid, 1987, 176ss.

2 J.C. Cavadini, The Last Christology of the West. Adoptionism in Spain and Gaul, 785-820, Filadelfia, 1993.

3 Con todo, Cavadini admite la presencia de nestorianos, pero señala que el único propiamente tal seria Migecio (22s). Sin embatgo, resulta dificil asumir un Migecio, destacado nestoriano, propugnando específica devoción a Roma. No veo muy clara la disgresión del autor en torno al magister Salibaniorum, hay que tener presente que Alvaro de Córdoba, separándose de Elipando, dice nos non Sabellianam uberesems predicamus (Ep., IV, 27).

Por otro lado, hay que tener en cuenta, frente a la propuesta de acomodación con el Islam, que Félix, al decir de Alcuino, escribió un tratado antimusulmán.

Hispania, L.VIII/3, núm. 200 (1998) 971-993 
tológica occidental, criticaba a Migecio que afirmaba que la Segunda Persona era facta o assumpta, lo que implicaba su aparición en el tiempo. Frente a él, el toledano destacaba su proveniencia del Padre antes del tiempo.

Era consciente Elipando de que convenía precisar esa relación entre el Verbo y la humanidad y entre Cristo y el Padre en el marco de la salvación. Establece entonces que Jesucristo es adoptivo en su humanidad, pero no en su divinidad, ya que en ésta es Hijo del Padre antes del tiempo. El Hijo es engendrado por el Padre non adobtione sed genere, no por la gracia sino por naturaleza, hecho hombre de la Virgen, no por generación sino por adopción, y no por naturaleza sino por la gracia. Siguiendo la tradición hispana, el Hijo era unigénito por su divinidad, pero primogénito por su humanidad

El problema radica en que Beato considera que el vaciamiento de la divinidad que ha de hacer el Logos en la encarnación llega demasiado lejos en Elipando. Destaca precisamente los textos de Elipando en que éste subraya que tanto los hombres como Cristo son adoptivos, que los hombres y el Hijo son cristos y, más aún, que Cristo es siervo entre los siervos-hombres [Apol. I, 49, $1087 \mathrm{ss}$ ]. Frente a lo que entiende como excesiva asimilación humana del toledano, Beato señala que Cristo es verdadera y apropiadamente el $\mathrm{Hijo}$; es el mediador, pero como tal está por encima de los hombres. Beato discute lo que le parece una inaceptable proximidad esencial entre Cristo y los humanos.

Para Cavadini las acusaciones de nestorianismo no provendrán de Beato, sino de los no familiarizados con la tradición teológica hispana, el papado o la Iglesia franca 4 . Para Alcuino, lo que pretenden los adopcionistas es destacar a un hombre con una existencia y persona aparte, de modo que subsiste como individuo después de la unión con el Verbo. En la misma línea que los nestorianos, los adopcionistas propugnaban una unión muy débil entre ambas naturalezas.

Quizás habría que haber subrayado esa impronta gótica en mayor medida. Con todo en numerosas ocasiones Cavadini acude a la influencia del XI concilio de Toledo y a la propia liturgia, precisamente en el sentido de mostrar que la propuesta teológica de Elipando era el corolario de otras, hispanas, producidas antes de la suya. Todas ellas venían a destacar la humanidad de Cristo frente a los acéfalos-monofisitas. Será esta insistencia, este respeto a la perfecta humanidad del Hijo, el que lleve a elaboraciones como la de las tres sustancias en la Segunda persona (divinidad, carne y alma) y, finalmente, al adopcionismo. Como muy bien señala Cavadini, se trataba de oponerse a Migecio y a la posibilidad de que el Hijo fuera hecho en el tiempo. Ante ello se destaca a un Verbo eterno que, al hacerse hombre, debe vaciarse de divinidad y adoptar una carne determinada. Elipando no podía transigir con facilidad en que Cristo fuera en su humanidad Hijo del Padre naturaliter: en ello seguía las pautas del XI de Toledo del 675. Ciertamente, no se trataba de lo que solía denominarse nestorianismo, pero hay un

4 Sin embargo, hay afirmaciones de nestorianismo en alguien tan familiarizado con la tradición visigótica como Benito de Aniano. Además, el paranestorianismo de Elipando es advertido en los argumentos empleados contra él.

Hiipania, LVIII/3, nüm. 200 (1998) 971-913.3 
terreno bastante próximo, el de subrayar la humanidad, que es el característico de la tradición hispano-goda en su radicalismo pro-calcedoniano.

$\mathrm{El}$ adopcionismo se convirtió en la doctrina oficial de la Iglesia hispana, lo cual no implica que no tuviera detractores entre la propia mozarabía. Sabemos por Jonás de Orleans y por el biógrafo de Benito de Aniano de su difusión en la Península, su propagación por la Septimania e, incluso, más allá. Alvaro de Córdoba sostiene que el adopcionismo se extendió hasta la condena realizada por el obispo Theudula, probablemente al frente de la sede sevillana en fecha que no podemos concretar, si bien es de suponer que en la primera mitad del siglo IX.

El libro de Cavadini deja abiertos algunos interrogantes ${ }^{5}$. Si, como estamos diciendo, el adopcionismo era la vía lógica de desarrollo teológico en la tradición hispana, se entiende que lo profesaran Elipando y Félix. Más aún que tuviera notable difusión en los territorios que habían pertenecido al reino godo y que entonces estaban en manos francas, obligando a la actividad del obispo Leidrado de Lyon y otros clérigos. Sin embargo, no resultan tan evidentes las evoluciones del adopcionismo en el reino astur, ni la trayectoria de otros personajes próximos a esta formación gótica, como Teodulfo de Orleans, el propio Benito de Aniano y, desde luego, Beato, quienes no participaton en estas propuestas. Sin duda, buena parte de sus motivos son teológicos: la formulación del Cristo adoptivo se aleja demasiado del Padre y puede problematizar la redención. Tenían la misma opinión que más tarde manifestará otro personaje profundamente enraizado en la cultura hispana, Alvaro de Córdoba, quien, conociendo bien la polémica, consideraba a Elipando un hereje (Ep., IV, 24) y compartía las críticas de Beato al metropolitano, volviendo a posiciones menos comprometidas que las manifestadas por el toledano.

Es posible que en la órbita franca hubiera ya una cierta animadversión previa, un prejuicio que pudo manifestarse en el envío de un obispo, ordenado por Wilchario de Sens con la aquiescencia papal, como si se tratara de tierras no cristianas. Puede que la información que tuvieran en el reino franco fuera en extremo incorrecta y se pretendiera una misión del tipo Bonifacio, es decir, dirigida a la conversión del infiel ${ }^{6}$. Sin embargo, de las actuaciones y problemas que se plantean al obispo enviado, un tal Egila, un bispanus según deducimos de su nombre, no parece derivarse que el motivo fuera la conversión de los musulmanes ${ }^{7}$. En este proyecto de conversión estaba profundamente interesada

5 Cavadini no está preocupado por las cuestiones históricas. Prueba de ello son algunos descuidos. Así, por ejemplo, Silo es hecho rey de León (p. 45). También las recientes referencias de D. Ganz "Theology and the organisation of thougho» en la New Cambridge Medieval History, Cambridge, 1995, 762ss.

6 Amman, L'époque carolingienne, París, 1947, 130. Abadal, 41.

7 Tampoco hay que olvidar otro precedente como el inglés, que también suponía colectivos cristianos, si bien la misión romana los marginaba, apuntando la heterodoxia de su fe. Así se explicaria la referencia a pro orlbodoxae fidei sanctaeque catbolice Ectlesiae predicatione de la primera carta de Adriano. La insistencia en el examen de la ortodoxia de Egila puede reflejar un cierto resquemor hacia la fe de los hispanos.

Hihpania, LWH1/3, núm. 200 (1998) 971-993 
la Iglesia franca y el propio Carlomagno, como testimonia la segunda carta pa$\mathrm{pal}^{8}$. Este es, sin duda, un elemento a resaltar, como hizo Abadal, y debe relacionarse con las intenciones imperiales de la corte franca.

Si bien Egila acabó participando en las teorías de Migecio, no resulta tan evidente que el motivo primatio de la misión fuera la conversión de este grupo: hay que recordar que el nombre del hereje resultaba desconocido para el papa y que Egila hace una consulta a Roma sobre temas conflictivos, por lo que no parece que tuviera una opinión definida al principio, lo que excluye una intervención diseñada desde su origen contra los migecianos.

El desplazamiento de Egila hasta las posiciones de Migecio puede resultar sorprendente. Es posible que su formación teológica no fuera muy densa, quizás en Sens tampoco eran capaces de determinarla o aumentarla, pero, sin duda, ciertos elementos debieron facilitar la aproximación de Egila a los migecianos 9 . Quizás, principalmente, la importancia conferida a Roma por Migecio; otros temas como su enfrentamiento a la confraternización con los infieles y posiblemente el cómputo pascual pudieron favorecer esta vinculación.

Como defendía Abadal, estamos ante una serie de acontecimientos que testimonia la disolución que se ha producido en la Iglesia hispana. No sólo por la herejía migeciana y el decantamiento de Egila, sino por el hecho de que Beato, un monje lebaniego, se permite discrepar de las decisiones tomadas en concilio, el reunido en Sevilla, o, en cualquier caso, de lo afirmado por la sede toledana. Pocas décadas después del fin del reino de los godos la Iglesia hispana pasaba por momentos de notable crisis.

Diversos elementos confirman la progresiva desintegración de la Iglesia goda. Por un lado, Elipando escribe a Félix para conocer su opinión cristológica, de lo que cabe deducir que su contacto no era muy efectivo y no parece que el prelado urgelitano hubiera asistido al concilio de Sevilla, reunido poco antes con motivo de la condena a Migecio. Más clara resulta otra indicación. La carta de Elipando a Fidel refleja el protagonismo del metropolitano frente a que le parecen desviaciones heréticas del norte peninsular, llegando a amenazar con la reunión de un concilio como ya había ocurtido en Sevilla contra Migecio. Por tanto, la Iglesia hispana de finales del VIII estaba notablemente inconexa, no se reunía en concilios sino en ocasiones muy especiales y parece haber tenido dificultades para acceder a unos personajes refugiados en

8 Como apuntó Abadal, el hecho de que esta documentación se haya guardado en el Codex Carolinus muestra el interés regio.

9 Amman ubica la acción de Egila en la región de Granada. Suele hacerse de él obispo de una sede particular, en virtud de una nota de Flórez aparecería su nombre en un episcopologio de Elvira ( $E . S ., \mathrm{V}, 340$ ). Sin embargo, suele identificársele con un Agila que fue condenado como hereje en el concilio cordobés del 839. Collins hace a este Agila de Ementie (La conquista árabe, Barcelona, 1991, 193s; texto en ed. Gil, 6) obispo de Mérida. En cualquier caso, me patece más apropiado -inciuso por razones geográficas- liacetlo de Mentesa. La sede emeritense está representada en el concilio por el obispo Ariulfo.

Hli.punia, LVIIJ/3, núm. 200 (1998) 971-993 
Asturias. Era el metropolitano de la antigua sede regia quien tenía que hacer presentes los elementos unitarios.

Sin embargo, la autoridad de Elipando sí podía provocar el cisma en lo que el propio Beato llama Iglesia asturiana. Sólo cuando Fidel difunde la respuesta de Elipando se produce ese debate que hubo de ser considerable, por lo que cabe pensar que hasta entonces las críticas de Beato no habian alcanzado resonancia suficiente para dejar patente el conflicto. $\mathrm{El}$ asunto es de interés, pues apunta a un menor protagonismo intelectual de Beato en el reino asturiano en las vísperas de la polémica, en la que también participó su amigo y discípulo Eterio de Osma ${ }^{10}$. De sus palabras se deduce que el otro sector era mayoritario también en Asturias y que quizás hubo algún intento de eliminar con ayuda del poder civil el «error beatiano» (Apol. I, 13). Entre los elipandianos estaba Fidel, que difunde la carta en perjuicio de Beato y Eterio sin que éstos la conocieran y que en el Apologeticum dirigido a Elipando aparece como Fidelis tuus ${ }^{11}$ con toda la carga de sentido que tiene. Jonás de Orleans testimonia su propagación en Asturias y Galicia y su pervivencia todavía durante bastantes años ${ }^{12}$.

La controversia no culmina con el beatiano Adversus Elipandum, sino que continúa con participación creciente del papado y de la Iglesia carolingia frente al metropolitano de Toledo y el obispo Félix de Urgell. Los derroteros que va tomando son significativos, en tanto que se precisa la opinión sobre el otro, lo cual en cierta medida implica simplificaciones, a veces muy notables, propias de las confrontaciones teológicas.

Elipando, siguiendo las tradiciones de la Iglesia visigoda, resaltaba la perfecta humanidad del Cristo hombre y, precisamente en la línea de esa completa humanidad, destacaba la proximidad de Cristo a sus hermanos ( $H e b ., 2,17)$ y en ese sentido la primogenitura de Cristo. María era la transmisora de la carne in fetum, criticando el toledano a Alcuino, quien, en opinión de Elipando, negaba que Cristo hubiera recibido la carne de la Virgen. La polémica parece haberse reforzado sobre este punto, la estirpe humana de Cristo ${ }^{13}$. De ahí la insistencia del toledano sobre el origen humano de Cristo, ... radix Iesse ... de stirpe Abrabam ....

Elipando advierte uno de los núcleos del debate cuando se enfrenta a las opiniones de Beato. El lebaniego, según Elipando, sostiene que in maternis uis-

10 Resulta complejo calibrar el protagonismo de otros. Un obispo de nombre Ascárico, que había escrito a Elipando preguntando por la opinión ortodoxa sobre el tema, debia ser conocido al abad Fidel, pues el toledano se lo menciona. No sabemos su sede y, en cualquier caso, no consta que actuara contra Beato y Eterio. Es verosímil que sea el mismo que escribe una carta a Tuseredo (Corpus Scriptorum Muzarabicorum, ed. Gil, 1, 114ss), en donde se advierten preocupaciones de suficiente nivel, pero no hay mención del adopcionismo. Sea como fuete, la polémica adopcionista no le era conocida en ese momento.

11 (II, 5). Parece que Fidel habia informado a Elipando de las opiniones de Beato.

12 De praedestinatione, praef. (PL CVI, 310). No creo que esté acertado Defoumeaux en fechar el viaje de Jonás hacia el 785 ("Carlomagno y el reino asturiano", en Estudios sobre La monarquia asturiana, Oviedo, 1971, 20; p. 94). Debió producirse, al menos, una veintena de años después. aevi, II).

13. Ep. episcoporum Hispaniae, 1, 35ss, 2, 4s; Ad Alcbuinum, 3, 1ss, 25ss (M.G.H., Epistolae Kar.

Hi.pania, I.VIII/3, núm. 200 (1998) 971-993 
ceribus carnem adsumens, lo que venía a implicar más un lugar y una cierta pasividad humana de la Virgen en la encarnación, mientras que Elipando afirmaba de maternis uisceris ..., reforzando la idea de procedencia de la carne, la actividad de María y, por supuesto, cierta independencia ${ }^{14}$.

La sensibilidad de Elipando se alzaba contra propuestas que oscurecían la humanidad de Cristo, cuando era preciso que el Verbo se hiciera carne para que se produjera la redención: sólo el Hombre podía padecer y morir en la cruz. Reprocha a quienes atribuyen a una naturaleza lo que es característico de otra. Se enfrenta a quienes niegan la verdad de la carne de Cristo y la honra debida a la misma y se pregunta cómo se puede negar aquello que es verdaderamente lo que salva ${ }^{15}$.

Un texto de Basilisco se nos ha conservado en la correspondencia de Alvaro de Córdoba. Se trata de una crítica al adopcionismo realizada por alguien conocedor de las propuestas elipandianas. No es extraño que incida sobre los elementos que acabamos de señalar. Basilisco critica a Elipando, acusándole de afirmar que el Padre no creó la carne. Dios engendra al Hijo, pero la carne procedería de la realidad corpórea, la madre. Resulta una encarnación demasiado escindida entre un $i b i$ y un bic. Tratando de lievar al absurdo las afirmaciones adopcionistas, se pregunta por qué, si Elipando divide a Cristo, ya que considera la carne adoptada, no escinde también al hombre, pues de sus padres no procede el alma ${ }^{16}$. Habiendo una única persona en Cristo resulta ridículo sostener que no es Hijo verdadero y propio de ambos padres ${ }^{17}$.

Benito de Aniano, un personaje de origen hispanogodo oriundo de la Gothia, que ahora vivía en tierras controladas por Carlomagno, escribió diversas obras que afectan la polémica adopcionista. Benito muestra su interés por oponerse a las minorizaciones excesivas que los herejes hacen del Hijo. Ante tal tendencia, que ha llegado a no considerar a Cristo verdadero Hijo, advierte de la procacio adversus totius salutis dispensationem, es decir, la propia salvación quedaría así puesta en entredicho, pues no ha afectado al verdadero Hijo de Dios. Ahora, continúa Benito de Aniano, al afirmar algunos que en la cruz sólo es crucificado el Hijo adoptivo, se pone en peligro la redención. Opone a esta amenaza la divina maternidad de la Virgen, madre de Dios ${ }^{18}$.

La percepción que Benito tiene del adopcionismo es más claramente la de un movimiento nestoriano. No hay dos hijos, uno del Padre y otro de la madre,

$14 A d A l c, 6,26 \mathrm{~s}$. En general suele emplear esta terminologia, si bien hay excepciones: for mam serui de gloriosa Dei wirgine $(3,2)$; de utero uirginis $(3,25)$, etc.

15 Ibid, 9, 130ss, 144.

16 Este argumento lo encontramos también en la carta de Alcuino a Guntroda (Ep. 241). Es posible la coincidencia, pero también la comunicación entre Basilisco y Alcuino.

17 Ep., IV, 28, ed. Gil.

18 Tratando evitar el escolio afirma que no hay adopción, ni tampoco asunción como si la carne ya existente fuera asumida, sino que simplemente el Verbo se hace came, si bien hay una disminución, un vaciamiento, como cuando el tico se hace pobre, pero virtus y sapientia son las que corresponden a la divinidad y no a la humanidad (Adv. Fel, PL CIII, 1400s).

Hispania, LVIIJ/3, núm. 200 (1998) 971-293 
sino un único y mismo Cristo verdadero Dios y hombre. No hay un Cristo que nace, otro que muere o es sepultado, sino uno que es Hijo propio de Dios ${ }^{\prime \prime}$.

En su carta a Félix de Urgell Alcuino viene a incidir de nuevo en la idea de salvación: un hijo adoptivo, es un falso hijo, por tanto es falsa la salvación. Quien nace de María no es adoptivo sino verus et natus Deus ${ }^{20}$. Resulta contradictorio ser Hijo propio y adoptivo al tiempo, se es uno o lo otro. En la encarnación se produce una exaltatio de la humanidad ${ }^{21}$, hay algo extra que es recibido por la divinidad, no una exinanitio en la línea interpretativa de Philip., 2, 6-7. Alcuino progresivamente, lo ha señalado Cavadini, tiende a homologar el adopcionismo con el nestorianismo y a considerarlo un error en tanto que propugna dos personas.

Puede parecer que el reino astur quedó al margen de la polémica y que Basilisco fue un experto marginal, en el sentido de que la controversia adopcionista se habria desintegrado en el norte peninsular y que constituía una cuestión y preocupación casi de anticuario.

En primer lugar, una importante cuestión, no especialmente considerada, es discernir si fue la facción de Beato quien impuso su versión en Asturias y, por otro lado, si puede hablarse de un desarrollo de la polémica en el reino.

Si las propuestas beatianas se impusieron, hay que pensar que el poder tomó partido por las mismas y que la influencia de Beato fue en aumento. Sólo de este modo pudo quebrarse el prestigio de la tradición goda, representada por el metropolitano de Toledo, y alterar la balanza en cuanto a los apoyos obtenidos por cada facción religiosa.

Buena parte de lo que puede decirse al respecto depende de si consideramos a Beato de Liébana autor del himno dedicado a Santiago, el $O$ Dei verbum, publicado también en la edición antes referida. En el acróstico del citado himno se ensalza la figura del rey Mauregato, pudiéndose leer: $O R A E X$ REGVM REGEM PIVM MAVRECATVM AEXAVDI CVI PROVE OC TVO AMORE PREVE.

Sabemos que los reyes Silo y Adosinda, no teniendo descendencia, prepararon el acceso al trono del hijo de Fruela I, Alfonso II, y por ello precisamente el joven Alfonso desempeñaba en la corte una posición de privilegio, palatium guternauit dice la rotense, siguiendo lo que parece una pauta de la monarquía astur, por la que el sucesor ocupaba la dignidad de comes palatii, un cargo novedoso con respecto a la tradición goda. De hecho, Alfonso ocupaba esa dignidad, porque Silo no tenía hijos de Adosinda ${ }^{22}$.

1) Ibid, $1407 \mathrm{~s}$.

20 Ep. 23, M.G.H. Ep. Kar, aevi, II, p. 62.

2) Ep., 166, p. 273. Vid., Cavadini, 93.

22 Rot., 18. A. Isla, «Nombres de reyes y sucesión al trono (siglos VIII-X)», Studia bistorica, XI (1993), 16. Barbero y Vigil, La formación del feudalismo en la Peninsula Iberica, Barcelona, 1978, 315. No sería tanto una asociación al trono, cuanto una decisión sucesoria. 162ss.

Sobre la constitutio de Alfonso, "Consideraciones sobre el reino astum, Hispania, LV (1995),

IIlipanid, LVIII/3, núm. 200 (1998) 971-993 
A pesar de este proyecto sucesorio, un hijo ilegítimo de Alfonso I, Mauregato, se hizo con el trono y desplazó a Alfonso II. Parece que el joven príncipe ya había accedido al poder del que sería desalojado por la invasio de Mauregato. Las dos versiones de la Crónica de Alfonso III sostienen que el joven Alfonso marchó a refugiarse con los parientes de su madre en tierras alavesas.

Sabemos que la reina Adosinda ingresó en un monasterio. Con esta acción se seguían prácticas políticas visigodas que establecian la obligatoriedad de que las reinas viudas entraran en un monasterio ${ }^{23}$. Precisamente en la ceremonia de su profesión monástica se encontraron Fidel y Beato, siendo allí o inmediatamente después cuando éste tuvo conocimiento directo de la carta de Elipando, era el 26 de noviembre del $785^{24}$.

Díaz y Díaz propone entonces la dificultad de que sea el mismo personaje quien está presente en la entrada en el monasterio de Adosinda y el que escribe una loa tan notable al rey que tiránicamente había invadido el reino, quebrado la sucesión instituida y desplazado a Alfonso II del trono. Si el lebanjego pertenecía al grupo de Adosinda, no podía luego participar de ese modo tan adulatorio en el entorno de Mauregato ${ }^{25}$. Díaz también establece una dura dicotomía entre los dos bandos en favor o en contra de Mauregato, coincidiendo con las dos facciones de la controversia adopcionista ${ }^{26}$.

Cabe, sin embargo, advertir que este tipo de doble posición no serja absolutamente desconocida en la tradición eclesiástica. Así, la actitud al menos acomodaticia de Eugenio con respecto a Chindasvinto y, mucho más ciara, las cambiantes opiniones de Isidoro de Sevilla con respecto a diversos reyes, producto de unas relaciones determinadas entre el poder regio y la jerarquía eclesiástica.

Otros aspectos pueden resultar clarificadores. En primer lugar, si, como parece, el rey Silo había muerto en el 783 y Alfonso había sido expulsado muy poco después, la entrada en un monasterio de Adosinda a finales del 785 se producía en un momento en que el nuevo monarca ya estaba sobradamente afirmado en el reino y la teina no implicaba excesivo riesgo político. Beato, al responder a Elipando, insiste en que Fidel ha retenido la carta del toledano por más de un mes y que sólo había llegado a sus manos cuando se entrevistaron, no porque él, dice, quisiera ver la carta cuya existencia ya conocía, sino por coincidir en la ceremonia de ingreso monacal de Adosinda. Quiero decir que existe una posibilidad muy alta para explicar el motivo por el cual el monje lebaniego se personó en aquella ceremonia, acceder a una misiva cuya lectura le había estado vedada.

De todo ello, nada nos hace pensar que la propia profesión monástica de la reina fuera un acto reivindicativo en el que sólo habrían de estar presentes los

23 Canon V del conc. de Zaragoza del 691 (Vives, Concilios uisigóticos e bispano-romanos, Barcelona-Madrid, 1963,479 s).

${ }_{24}$ Apol., I, 1.

25 «Los himnos en honor de Santiagon, en De Isidoro al siglo XI, Barcelona, 1976, $247 \mathrm{ss}$. Alli se edita el himno, 239ss.

26 Ibid., p. 253 y nota 34.

Hispania, LVIl1/3, núm. 200 (19\%8) 971-993 
íntimos partidarios de la causa de Adosinda y de Alfonso II. Como señaló Sánchez Albornoz, alli se encuentran tanto Fidel, cuyas vinculaciones con Elipando parecen evidentes, como Beato, sin duda interesado por acceder a la misiva, pero quizás un tanto marginado de la pugna política por su residencia lebaniega. Esta asistencia no parece haberle afectado negativamente en su carrera posterior, lo que confirmaría el escaso sentido partidista del acto.

Por otra parte, hay diversos elementos para suponer la autoría beatiana del himno. Pérez de Urbel ya destacaba uno, Beato era la única persona en el reino de Asturias capaz de escribir esta obra ${ }^{27}$. Quizás con Pérez de Urbel puedan señalarse otros argumentos al respecto algo menos lapidarios. El más claro es el ambiente apocalíptico que está presente en toda la obra. Sorprende que un himno dedicado a Santiago tenga una apoyatura tan directa en textos tomados del Apocalipsis. Se está así en la línea de una actitud que tiene en Beato de Liébana su más destacado exponente. Había escrito en el 776 su Comentario al Apocalipsis- lo revisaría más tarde al hilo de la polémica adopcionistamostrando su interés por el tema, no sólo desde una postura intelectual, sino también en el pleno convencimiento de la inminencia del fin de los tiempos. Pérez de Urbel y González Echegaray han destacado cuánto debe el himno al Comentario y al Apologético ${ }^{28}$, tanto en citas directas como en influencias más tenues. Díaz duda de la directa vinculación, pero lo que resulta indudable es la presencia del Apocalipsis en el himno.

Otro de los temas novedosos y coincidentes es el referido al apóstol Santiago que se recoge también en el Comentario de Beato ${ }^{29}$. El objetivo del himno es precisamente destacar la predicación jacobea y la posición patronal del apóstol. Estamos ante una innovación con respecto a la tradición visigoda que no consideraba esta presencia de Santiago en la Península ${ }^{30}$. En el himno el apóstol es llamado caput, tutory patronus de Hispania. En contrapartida le competen misio-

27 "Orígenes del culto de Santiago en España», Hispania Sacra, V (1952), 16ss. Vid., Sánchez Albornoz, «En los albores del culto jacobeo», Origenes de la nación española, Oviedo, 1974, II, 385ss.

28 Ob. cit., 666ss.

29 En el Comentario Beato se basa en el modelo trazado en las Etimologias al referirse a patriarcas, profetas y apóstoles. Isidoro y tras él Beato establecen la equivalencia entre Mateo y Levi, ya que aquél pertenecía a esta tribu (Etym., VII, 9, 17; Com. II, 3, 45), que, en cambio, no es recogida luego en el listado beatiano de los apóstoles con las áreas de predicación correspondientes a cada uno. Alli, como se había producido en el Brevianium apostotorum y también en la interpolación al $D \ell$ ortu, se le otorga Macedonia a Mateo y se afirma Iacobus Hispaniam, ocupando el cuarto lugar de ia nómina apostólica, siguiendo directamente las instrucciones del texto del De ortu en el que a Santiago se le supone quartus in ondine. En diferentes ocasiones el autor del himno se aleja del comentario y vuelve a las Etimologiar, como cuando señala la predicación de Judas en Edesa, que falta en la lista, quizás porque no podía rebasar el número de doce, lo que se hubiera conseguido al estar incluido Pablo, de hecho, poco antes había recogido esta información (53).

30 En su De comprobatione aetatis sextae Julián de Toledo presenta a Mateo como apóstol en Macedonia, pero se limita a vincular a Santiago con Jerusalem (Iacobus Hierosolymam ... illustrat). Otra cosa hubiera dicho si Isidoro de Sevilla hubiera sostenido la predicación hispana del Apóstol.

Hipunia, LVIII/3, núm. 200 (1998) 971-993 
nes de protección - -suave pastor le llama el texto- . Esta situación queda destacada sobre el rey, clero y pueblo y, si cabe, más aún sobre el primero, ya que el acróstico del himno refleja el protagonismo de Mauregato.

Con respecto a la atribución puede alzarse otro problema, como de hecho apunta Díaz. Este es un aspecto importante, pues también depende de él la fuerte dicotomía politico-religiosa trazada por Díaz. Es que en el himno no aparece huella alguna del conflicto adopcionista. Tampoco sería necesario los argumentos $e$ silentio resultan a menudo dificiles de manipular-, porque si fuese cierto que no es antiadopcionista, Díaz no muestra elementos de lo contrario, contrastaría con este enfrentamiento eclesiástico y político que él realza y presenta como dominador de la escena política astur.

En cualquier caso, es factible una propuesta de lectura que resalte lo que algunos elementos del himno pueden reflejar en el seno de esta polémica. Es decir, trataremos de presentar una hipótesis que engarce el himno en la controversia, si bien reconozco que no se trata de coincidencias textuales, de manifestaciones apodícticas que incidan en las ftases más tópicas de la cuestión, pero quizás un himno litúrgico dedicado a Santiago no era el género literario más apropiado para que se produjeran. Con todo, creo que su conjunto puede proporcionarnos una impresión suficiente. Es decir, la acumulación de elementos en un momento en el que, por haberse desatado ya la polémica, no podría obviarse la toma de partido, resulta significativa de la postura del autor. Al tiempo, buscaremos una explicación razonable de lo ocurrido en aquellos decenios con respecto a la controversia.

La primera estrofa de las doce del himno dice así;

O Dei Verbum Patris ore proditum

Rerum creator et verum principium

Auctor perennis, lux origo Luminis,

Enixus alvo gloriose virginis

Xriste, tu noster revera Emmanuel

Esta estrofa podria ser un alegato antiadopcionista, destacando los elementos más simples, pero, al tiempo, básicos de la refutación beatiana de Elipando, tal y como - conviene tenerlo presente - la presenta el propio Beato. En la tradición agustiniana el Hijo en la forma de Dios, es decir, según la naturaleza divina, es el Verbo, por quien fueron hechas todas las cosas, como repetidamente insistió Agustín de Hipona, destacando la creación del Padre per Verbum, es decir, es la Palabra salida de la boca de Dios la que crea ${ }^{31}$. Los siguientes términos vienen a insistir en la divinidad del Hijo: creator, principium, auctor. Mas en los dos últimos versos se resalta la procedencia de su humanidad -en su forma humana nace de mujer para la redención de los hombres - ${ }^{32}$. El último verso da la clave, es Dios quien está con nosotros. El Hijo de Dios e Hijo del

31 Vid., De Trinitate, II, 10.17.

32 Agustin, De Trin. I, 7. 14

Hispania, LVIII/3, núm. 200 (1998) 971-993 
Hombre es verdaderamente Cristo-Dios. La humanidad de Cristo no ha desvirtuado, disminuido o afectado la divinidad ni la unidad del Hijo.

Hay que recordar que lo que provocó el cisma a fines del VIII, la escisión en dos bandos, fue la duplicidad de Cristos (Apol., II, 29). El Cristo de Elipando, dice en $A p o l$., I, 48, es creador en la medida en que es Hijo por naturaleza, no por adopción. En ello se continuaba la larga tradición de los estudios trinitarios, pero la insistencia generaba dificultades. Dicho de otro modo, para Beato Elipando está escindiendo a Cristo: por un lado el que es verdaderamente Dios, el que es naturalmente Hijo de Dios y, por otro, el que no lo es, porque lo es sólo adoptivamente ${ }^{33}$. A esta propuesta Beato le opone la verdadera y apropiada filiación de Cristo. Ante el Hijo demasiado rebajado de Elipando, enfrenta un verdadero Dios, un Dios que es anunciado por el ángel como magnus et Filius Altissimi $(1,8)$.

Lo que esta primera estrofa quiere decir es que el Hijo de Dios, el creador y verdadero principio, es también el que salió del vientre de María, apropiada* mente Dios con nosotros. O sea que, incluso en su humanidad, Cristo es el verdadero Hijo del Padre, no un Dios disminuido. El mismo que es verdadero Hijo de Dios, lo es de la Virgen, verdadera madre de Dios. Son herejes como los maniqueos - y algunas veces Elipando es comparado a éstos (I, 118)quienes afirman «las cosas visibles e invisibles no fueron creadas por quien nació de la Virgen, sino por el que se engendró igual a sí mismon (Apol, II, 59), ya que para Elipando el nacido de la Virgen no es Dios, sino sólo hombre (Apol, II, 24), mientras que Beato resalta la unidad personal, de modo que ipse sit Deus qui est homo (II, 76).

Beato recoge la profecía de que el Anticristo disuelve a Jesucristo $(I I 0,4,3)$. Frente a ellos sostiene que quien es el Hijo de Dios es Jesús, al que parió María, verdadero Dios (I, 8; I, 13; II, 6). A este verdadero Hijo de Dios, que es adorado y reverenciado, será quien crucificará Poncio Pilato (I, 13).

El Hijo de Dios, al asumir la humanidad, fue hecho sacerdote y así por él podemos ofrecer una víctima viva al Padre. Esto lo logra en virtud de la asunción de la naturaleza humana $(A p o l$, II, 57$)$. Así es un único Cristo, una única persona, si bien con una doble naturaleza, rey y sacerdote, como se dirá al inicio de la segunda estrofa del himno.

No podemos saber con seguridad si el himno fue obra de Beato, pero sí cabe destacar la impronta antiadopcionista; también su huella apocalíptica, presente en diversos elementos ya señalados y en el propio protagonismo del $V e r$ bum Dei (Apoc., 19, 13). Además, hay deudas con las obras beatianas y coincidencias en la promoción de la predicación de Santiago en España. Por todo ello resulta bastante verosímil la autoría del monje lebaniego.

Parte del éxito de la obra de Beato radica en su capacidad de engarzar en lo que parece haber sido un sentimiento extendido en el reino. La convicción en la proximidad del fin de los tiempos estuvo notablemente difundida en esas

33 Hay resonancias agustinianas, En. in psalmis, 44, 4 y 5 (PL, XXXVI, 496).

Hi.pania, LVIIJ/3, núm 200 (1998) 971-993 
décadas. Algo de ello puede derivarse de la referencia a la sexta edad del mundo que figura en la lápida dedicatoria de la iglesia erigida por Fávila, el hijo de Pelayo. Obviamente, Beato ejemplifica estas tendencias. No sólo por su obra culta, el Comentario y quizás otras, sino también por su creencia en la Parusía. Quizás exagerara Elipando para ridiculizar a su adversario Beato, pero algo de verdad nos cuenta al señalar cómo el lebaniego había profetizado la llegada del fin del mundo en víspera de Pascua. El pueblo ayunó esa noche en preparación del acontecimiento, excepto un tal Ordoño, cuya actitud da motivo a redondear la chanza ${ }^{34}$. Por más que se destaque como una ácida burla, el testimonio refleja una profunda creencia en Beato y su entorno más allá de una simple afirmación libresca.

Un personaje convencido de la proximidad de la Parusía y decididamente enfrentado a las propuestas cristológicas de Toledo y, por extensión, al conjunto de la Iglesia hispana ${ }^{35}$, escribe unos versos laudatorios al rey Mauregato. Aunque no sea este autor Beato, no hay evidencia de un posicionamiento coincidente de las opciones cristológicas y políticas con propiciar el acceso al poder del nuevo rey astur. Mientras que, en todo caso, suficientes argumentos de afirmación antiadopcionista se hacen presentes en el himno dedicado al rey.

Por otro lado, resultaba de notable conveniencia para Beato, Eterio y los suyos que el rey se decantara a su favor. En primer lugar, para que desoyera las reclamaciones de Elipando. Mas también, porque esa voluntad regia era precisa para culminar su proyecto. La propuesta de Beato es ciertamente dura: cerrar las puertas a todo aquél que no profesara la fe según él la entendía. En $A p o l$., I, 23 (también I, 36) afirma que el que venga de otras regiones o el que provenga de nostris finibus y no comparta esta fe no ha de ser recibido en la Iglesia. En una tierra que estaba recibiendo un nutrido grupo de emigrantes desde el sur, resultaba una propuesta complicada, en la que era imprescindible controlar ese flujo para poder imponerse a la herejía adopcionista, para lo cual era urgente el apoyo del poder regio. Sabemos que, finalmente, sus planteamientos en este sentido no prosperaron, pero ignoramos las tensiones y problemas que pudieron desarrollarse en aquellos años.

Por tanto, nada obsta para que de Beato o de su círculo procediera el himno. Una pieza que realizaba un giro copernicano en la tradición, propugnando unos orígenes apostólicos, jacobeos, para el cristianismo hispano.

Muy poco sabemos de los años inmediatamente posteriores. Mientras reinaton Mauregato y Vermudo la polémica adopcionista se desarrolló en todos los sentidos, pero carecemos de referencias precisas con respecto a lo que pasó en el reino astur.

El reinado de Alfonso II constituye un punto de inflexión considerable en la historia del reino septentrional. Algunas de sus actuaciones lo muestran claramente. Tenemos noticias de su unción, lo que supone una novedad por lo

34 Ep. episcoporum Hispaniae, 5, 66 ss.

35 No se olvide la recurrencia de Beato con sespecto a la Iglesia de Asturias y sus cismas. Resulta mucho menos preocupado por lo que ocurta más al sur. 
que sabemos del reino astur y parece el elemento más claro de visigotismo de su reinado, lo que tampoco excluye otras influencias. Ya advirtió Menéndez Pidal que era un modo de dignificar su elección ${ }^{36}$. Sin duda trataba de reforzar su posición frente a posibles amenazas, luego bien visibles, pero habría de implicar también un cierto proyecto de actuación. Además, el monarca llevó a cabo un cambio de sede, un hecho nada anecdótico que refleja su distanciamiento con respecto a Pravia, la sede regia que establecieran Silo y Adosinda y en la que hemos de pensar que continuaron Mauregato y Vermudo.

Actúa también frente a los musulmanes. Si su regreso al trono puede estar relacionado con el fracaso de Vermudo en Burbia en el $791^{37}$, hay que señalar que Alfonso II tuvo un balance positivo en sus enfrentamientos con los andalusíes. Llevó a cabo también una política de buenas relaciones con los francos, con intercambios de embajadas y regalos, formando parte, como reino subsidiario, del panorama internacional de Carlomagno ${ }^{38}$.

En el 794 Carlomagno reunió un concilio en Frankfurt que condenó la adoración de las imágenes, supuestamente propuesta por Constantinopla en el concilio de Nicea del 787, y también el error adopcionista. Es sabido cómo las diversas fuentes francas matizan la procedencia de los asistentes a la asamblea. Para nuestro propósito lo interesante es que los Anales de Aniano, a los que hemos de suponer bien informados por su atención a temas peninsulares, citan los asistentes de modo más amplio, haciendo referencia no sólo a los obispos, como hacen otras fuentes, sino también a los abades, monjes, presbíteros y otros clérigos. Así podían subrayar la presencia de Benito de Aniano y alguno de sus monjes. Además, se indica la participación de personajes procedentes de Gallecia, lo que apunta a que clérigos del reino astur también acudieron a la asamblea. Por tanto, durante los primeros años del reinado de Alfonso II había suficiente interés en el reino astur por las disputas religiosas del momento y por las relaciones con el reino franco como para enviar una legación al concilio ${ }^{39}$.

Entre los embajadores al reino franco está presente un tal Basilisco que es posible relacionar con el mencionado por Alvaro de Cótdoba como polemista

36 "La historiografía medieval sobre Alfonso II», en Estudios sobre La monarquia asturiana, Oviedo, 1971 (2), 23s.

37 Quizás la derrota de Vermudo en el Burbia que Sánchez Albornoz relacionó con la campaña de Yusuf ibn Bujt en tierras occidentales en el 791 desacreditó al monarca. Debe localizarse en el Bierzo («La derrota del Burbia», Orígenes ..., I1, 469ss., esp. 478ss). Más o menos voluntariamente debió ingresar en un monasterio, siendo sustituido por Alfonso II. Era el principio de un nuevo período en el cual los ataques andalusíes iban a ser mucho más frecuentes.

38 Este es el sentido de la afirmación de Eginardo. Otro tanto la de los Anales regios cuando, al narrar los regalos llevados por Basilisco y Froila (s.a. 798), dicen que más que tales parecían insignia vittoriae, es decir, los propios símbolos de la victoria que era preceptivo llevar al monarca (McCormick, Eternal Vittory, Cambridge, 1986, 376).

39 Texto en M.G.H., Script. I, p. 310. Abadal crèó que se trataba de una confusión del cronista, suponiendo que éste sostenía la presencia de obispos del norte peninsular, peto en realidad no dice que tales legados tuvieran la dignidad episcopal (93ss., esp. 98).

Hi.pania, L,VIII/3, núm. $200(1998) 971-993$ 
antielipandiano ${ }^{40}$. Por su parte, Beato parece haber enviado a Tours al monje Vicente para entrar en contacto con Alcuino. La disputa adopcionista, por tanto, formaba parte central de las relaciones de Oviedo con Carlomagno, en las cuales el reino astur habria de reforzar su determinación antiadopcionista.

El monarca astur desarrolló un verdadero programa constructivo. Sabemos que algunos de sus antecesores realizaron edificaciones individualizadas, pero ahora por primera vez, sirviendo luego de precedente en el reino, se efectúa una amplia tarea edificadora que pone en pie toda una gama de edificios en el entorno ovetense. En uno de ellos, en Santa María, estableció un panteón regio ${ }^{41}$, lo que debe ser relacionado con un proyecto de consolidación y desarrollo monárquico. Las fuentes coinciden en señalar diversos grupos de edificaciones. Por un lado, San Salvador, Santa María y San Tirso; por otro San Julián (de los Prados) satis procul a palatium, es decir, a cierta distancia del palatium, precisando la ovetense un estadio al norte del mismo, o sea ciento veinticinco pasos, por tanto unos 185 metros. Además, tanto la Albeldense como la Crónica de Alfonso III coinciden en resaltar la construcción de edificios regios, regia palatia, lo que reincide en su voluntad de fortalecimiento monárquico ${ }^{42}$.

Estamos ante un proyecto muy sofisticado, lo que excluye la casualidad. En el cerro del Oviedo primitivo había estado ubicada una iglesia dedicada al Salvador edificada por Fruela, según los epígrafes que traslada el Liber Testamentorum ${ }^{43}$. Alfonso sólo la habria restaurado y, por supuesto, ampliado en un proyecto en el que se añadían dos templos más, el de Santa María y el de San Tirso. Si en el de Salvador había doce altares dedicados a cada uno de los apóstoles, en la iglesia de Santa María había dos en honor de Julián y Esteban.

La elección de la advocaciones para templos y altares dista mucho de ser un elemento anecdótico ${ }^{44}$. Cuando Benito de Aniano realiza sus primeras fundaciones, su biógrafo pone buen cuidado en recoger la titulación de las iglesias y los altares y los motivos que han llevado a la misma. Los dos primeros templos

40 Ep., IV, 28. Abadal, 171. Sánchez Albornoz, «Basiliscus», en Origenes II, 757ss. Sin embargo, Diaz al hacer cordobés al escritor no parece que crea es el mismo personaje (De Isidoro al sigho $\left.X I, 73, \mathrm{n}^{\circ} 41\right)$.

41 Su situación a poniente puede estar relacionada con su uso funerario.

42 El argumento de Olmo Enciso sobre la visigoticidad del urbanismo ovetense quizás debería matizarse: ni siquiera poseemos un plano generaimente admitido ( palatinos en el contexto de la topografia urbana altomedieval de la Península Ibéricas, Congreso de Arqueologia medieval española, II, Madrid, 1987,350s). El estar ocupando una altura es posible que no sea vínculo suficiente; la referencias a la recuperación neogóticas de la crónica sirven para probar el goticismo urbanístico y viceversa.

43 Los publica Fernández Conde, E/ Libro de los testamentos, Roma, 1971, 378s. Las crónicas astures no refieren esta previa fundación. No puedo por menos de señalar la extrañeza que me produce la peculiar amenaza -presente en el epigrafe del lado izquierdo-- de pérdida del sacerdocio que tecaeria sobre el clérigo que olvidara realizar misas por Alfonso II.

44 García de Castro critica las observaciones de Uría Ríu sobre las advocaciones de los templos que considera uexplicaciones personalistas" (Arqueologia cristiana de La Alta Edad Media en Asturias, Oviedo, 1995, 454 y 513). 
se construyen en honor del Salvador y de Santa María. Es extraordinariamente significativo que la primera iglesia se dedique finalmente a la Trinidad y se construya un triple altar, uno con tres aras, representando la unicidad y triplicidad trinitaria. Además, había otros tres altares dedicados a San Miguel, a los santos Pedro y Pablo y al protomártir Esteban. En la iglesia de Santa María había altares en honor a San Martín y a Benito de Nursia. También hizo construir una iglesia dedicada a San Juan Bautista.

Evidentemente habia todo un plan de afirmación de la ortodoxia trinitaria y cristológica. Presencia de las tres personas iguales en su naturaleza divina y expresión también de la naturaleza humana de Cristo a través de la Virgen y del propio Juan Bautista. Quizás estas manifestaciones buscaban mostrar ante los francos la ortodoxia de los bispani ${ }^{45}$; en cualquier caso se recogían preocupaciones tradicionales en la Iglesia hispano-goda. En la iglesia de la Trinidad se hacia referencia a los milites terrestres y angélicos: San Miguel, las cabezas apostólicas — también Roma-y el primer máttir; además, había otras figuras relacionadas con las preocupaciones personales, obviamente monásticas, de Benito de Aniano.

En Oviedo nos encontramos también con un proyecto que destaca la cuestión cristológica. Las crónicas insisten en la exacta titulación de San Salvadot. La rotense dice que se construye in bonore Domini et Saluatoris nostri Ibesu Cbristi y la ovetense incluso precisa más in nomine Redemptoris nostri Saluatoris Ihesu Christi. En la rotense se da el título de Dominus y se destaca el rasgo de Salvador del Hijo.

Dentro de la ambigüedad siempre presente, podemos deducir un fortalecimiento de la idea de salvación. Por un lado se incide en la conexión JesúsCristo y Salvador, dum Iesus Christus, propium est vocabulum Salvatoris (Etym., VII, $2,4)$. Jesús es el nombre que, según el ángel anunciador, ha de llevar el hijo que nacerá de María $(M t, 1,21)$, pero éste no es el hombre radicalmente escindido de un Cristo Dios. Estamos, pues, en la misma tesitura marcada por el $O D e i$ verbum. Quien es el verdadero Hijo de Dios es Emmanuel, que es el hijo nacido de María. La dedicación de templos a Jesús-Salvador testimonia esa importancia que en Occidente desde Agustín de Hipona se otorga a la mediación de Cristo.

Con todo, en un ambiente en el que se han producido controversias cristológicas en las que un sector, el adopcionista, es percibido por sus antagonistas como disgregador de la persona del Hijo, la advocación del Salvador asociada a la de María viene a reforzar la unidad de la divinidad y la humanidad en Cristo, así como que María es verdadera madre de Dios ${ }^{46}$, tema éste que, según los antiadopcionistas, era disputado por sus adversarios.

45 También el biógrafo de Benito insiste en la ortodoxia del personaje en la controversia adopcionista (17).

46 Así, la idea de que el Padre ha enviado a su Hijo al mundo para salvario $(10,3,17 ; \mathrm{I} I 0,4,14)$ es recordada por Beato para reincidir en la salvación frente a Elipando (Apoh, I, 42).

Hi.punia, LVIII/3, núm 200 (1998) 971-993 
Las otras advocaciones de altares e iglesias de Alfonso II han de tener relación con personales intereses y devociones del monarca. La presencia de doce altares en honor a los apóstoles tiene una cierta tradición ${ }^{47}$. El mártir Tirso recibía culto desde antiguo en Oriente y también en el reino visigodo. E] culto a quien se consideraba un mártir soldado, bien podía ser del agrado del combativo Alfonso II ${ }^{48}$.

La doble dedicación a San Julián parece anunciar una notable atracción sobre el monarca que ya señaló Uría. No en vano Julián es el mártir que, aun llevando a cabo un matrimonio no deseado con Basilisa, mantuvo la continencia a lo largo de su vida. Las fuentes cronísticas confirman la castidad del monarca y resulta lógico que se proveyera de modelos de este tipo de actitud tan poco usual entre los monarcas de su tiempo. Sobre esta situación se ha pensado que puede estar relacionada con el hecho de que Alfonso pasó por un monasterio y que allí pudo recibir órdenes religiosas que le impidieran el matrimonio. Mas, si la supuesta ordenación recibida no fue obstáculo para volver a reinar, no veo cómo pudo restringir su vida sexual, a no ser que existiera, en cualquier caso o además, la expresa voluntad del monarca ${ }^{49}$.

Los que vivieron unas décadas después del nonarca propiciaron su fama de santo; es probable, incluso, que ésta se iniciara ya en su reinado. La Albeldense concluye la reseña de su vida con la manifestación del deseo de que del reino terrestre pase al celeste, recogiendo un procedimiento que está presente en las alabanzas y exaltaciones regias propias de los concilios visigodos ${ }^{50}$. Las versiones de la Crónica de. Alfonso III son mucho más explícitas. En la reconsideración final de la figura de Alfonso II dicen que vivió largo tiempo casta, sobria, inmaculada, pía (la ovetense) o púdica (la rotense) y gloriosamente ${ }^{51}$. Lo que los

47 Es probable que estén en la línea de reforzar la idea del templo de Jerusalem, en donde habían sido colocadas las efigies de doce bueyes $(3 \mathrm{Reg}, 7,25)$. Isidoro de Sevilla había resaltado el paralelismo de los doce bueyes del templo de Salomón, quam duodecim apostolos credimus designari (Quaest. in Vet. Test., in III Regum, II, 8, PL, LXXXIII, col. 416).

${ }_{48}$ Garcia Rodríguez, E/ culto de los santos en la España romana y visigoda, Madrid, 1966, 216ss. Uria, "Cuestiones histónico-arqueológicas relativas a la ciudad de Oviedo de los siglos VIII al X》, en Symposio sobre cultura asturiana en la Edad Media, Oviedo, 1967, 294. En la passio de Tirso hay un notable alegato contra las imágenes (ed. Fábrega, Pasionario bispánico, Madrid-Barcelona, 1955, 31-33)

49 Sánchez Albornoz sugirió la «anomalía psicofisican del personaje («Mahamud» en Orígentes, II, 709). Por muchos motivos nada apremia a ir tan lejos.

50 Por ejemplo, la dedicada a Sisenando por el IV toledano: et post praesentis regni gloriam ad aeternum regnum transeat (ed. G. Martínez Diez y F. Rodriguez, 259, líns. 230s).

51 ... per multis spatiis temporum gloriosam, castam, pudicam, sobriam atgue immaculatam uitam duxit ... (Crónicas asturianas, ed. Gil, Oviedo, 1985, 22, pp. 141s). La segunda estrofa del himno Iste confessor Domini sacratus dice: Qui prius, prudens, bumilis, pudicus, / sobrius, castus fuit et quietus, / Vita dum proesens vegetavit eius / Corporis artus. El citado himno —en el Repertorium de Chevalier figura con el núm. 9136 - fue incluido en la recopilación mandada hacer por Cisneros, el Breviarium (PL, LXXXVI, 1016), pero está ausente de la tradición manuscrita visigodo-mozárabe. Al encontrarse presente en los manuscritos hímnicos de la más diversa procedencia, Blume no lo considera propio de la tradición visigodo-mozárabe, sino del acervo común hímnico y, por ello, lo

Hippania, LVIII/3, núm. 200 (1998) 971.993 
cronistas tratan de destacar es un determinado comportamiento en su dilatada vida, es decir, la vida santa del monarca. De hecho, han tomado estos calificativos del oficio que en la liturgia se llevaba a cabo en conmemoración de un confesor: pius, prudens, bumilis, pudicus, sobrius, castus fuit et quietus. Idéntica terminología para una vida semejante, el rey era asimilado a un santo confesor. El adjetivo glorioso tiene que ver con su condición regia, del mismo modo que la referencia in senectute bona de la rotense está relacionada con las biblicas palabras que comentan la muerte del rey David (1 Par., 29, 28).

En el año 812, en el contexto de la obra constructiva de Alfonso II y, por supuesto, de sus personales proyectos monárquicos, el monarca realiza una considerable donación a San Salvador de Oviedo. De ella se nos ha conservado un texto antiguo. Sin embargo, Barrau-Dihigo la creyó obra de un falsario del siglo XI, mientras Floriano afirmó su paleográfica corrección y su carácter original, lo que ya había criticado Millares y luego ha hecho Fernández Conde, si bien sosteniendo su autenticidad ${ }^{52}$. También es general el destacar su peculiaridad diplomática, pues resulta excepcional como concesión regia ${ }^{53}$.

El texto puede subdividirse en varias partes con cierta unidad. Un primer conjunto de frases constituye una verdadera invocación. En ellas se recogen diversos nombres de la divinidad. Son éstos, acompañados de algunas de sus fuentes:

Fons uitae ... Ps., 35, 10. Himno de San Félix de Gerona.

$O$ lux auctor luminis ... Himnos de San Félix y de Santiago ${ }^{54}$.

Alfa et omega, initium et finis ... Apoc., 1, 8; 21, 6 .

radix et genus dauid;

stella splendida et matutina ... Apoc., 22, 16.

Por tanto, los primeros términos del Testamento nos remiten fundamentalmente al himno a Santiago y al Apocalipsis como fuentes. Algunos de estos elementos figuran en el officium in die apparitionis domini, mezclados con otros textos apocalípticos si bien no con el himno, $\mathrm{O}$ lux $\ldots{ }^{55}$. La siguiente frase actúa como colofón de esta primera parte y confirma su contenido.

Christe Ihesu

supone de origen romano (Hymnodia Gothica, p. 44; lo edita Blume en Die Hymnen des Thesurus Hymnologicus, Anal Hymn., LI, 134s). Vid también Mearns, Earty Latin Hymnaires, Cambribge, 1913, 44.

El asunto es muy interesante y revela la posibilidad de conocimien to de materiales diversos. Con todo, tesulta cuestión extremadamente compleja y excede mi competencia; en cualquier caso no debería desdeñarse ninguna hipótesis.

52 Vid. Barrau, «Etudes sur les actes des rois asturiens», Reu. Hisp., XLVI (1919), 60, 116s; Floriano, Diplomatica astur, I, n1 24 con edición (119ss) y estudio (132ss); Millares, Paleografía española, Barcelona, 1929, I, 168s; Fernández Conde, El labro de los testamentos de la catedral de Oviedo, Roma, 1971, 118ss.

53. Esta originalidad quizás se deba a que carecemos de otros testimonios semejantes. Resulta interesante contrastar algunas de las partes del texto del 812 con la inscripción de fundación de Valdedios.

54 Para las fuentes del O Dei Verbum, vid. Díaz.

55 Antifonario visigótico mozárabe de la catedral de León, ed. Brou y Vives, Barcelona-Madrid, 1959 , fol. $85 \mathrm{v}$ y $87 \mathrm{v}$.

Hispania, LVIIJ/3, nútm. 200 (1998) 971-923 
qui cum deo patre et spiritu sancto

et super omnia

Deus benedictus in saecula .... Rom., 9, 5 .

En realidad, la frase en la epístola dice Cristus secundum carnem qui est super omnia .... Se entiende que se hayan introducido, como es frecuente en las invocaciones, las otras personas de la Trinidad. Al hacerlo, además, se estaba reforzando la idea básica, la divinidad de Cristo, y la unicidad divina. El contexto en la epístola nos muestra el sentido que se daba a la frase: es Jesús-Cristo, es el Dios hecho carne quien está junto al Padre y el Espíritu por encima de las cosas.

Se trata nuevamente de una afirmación antiadopcionista. A la cita recurren profusamente los polemistas antielipandianos. Jesucristo no es un hijo adoptivo o nuncupativo, sino que es bendito sobre todas las cosas ${ }^{56}$. El super omnia resulta un elemento importante en la apreciación de Beato. Cristo es un Dios por esencia sobre todas las cosas y no un dios no esencial entre las cosas, intra omnia. Se trata de Dios mismo, nacido de María y crucificado, pero muy diferente de los hombres. No es hombre con el Padre y el Espíritu Santo, sino que con ellos es Dios (Apol, $\mathrm{I}, 60)$.

Todo ello coincide con las primeras frases, en las que se realzaba por un lado la creación y la divinidad, al tiempo que la estirpe humana de Cristo. Sin quiebras, sin escisiones se presentaba frente al adopcionismo la unidad personal de un Cristo auténtico Hijo de Dios ${ }^{57}$.

Desde esta perspectiva se entienden algunos de los rasgos de este complejo texto. Su carácter es antiadopcionista y apocalíptico. Busca su inspiración en el himno a Santiago con el que comparte un proyecto de fondo, mientras que su originalidad formal ha de relacionarse con que en buena medida se está elaborando un texto de resonancias hímnicas ${ }^{58}$.

56 Apol, I, 17. Alcuino, Ep., 166, p. 272.

57 Cuando a mediados del siglo IX un monje de la altura teológica de Pascasio Radberto reincida en los problemas derivados del adopcionismo, centrará su atención en varios aspectos que convendría presentar para ver hasta qué punto nuestra aproximación a los textos procedentes del reino astur está en la línea de la preocupaciones derivadas de la heterodoxia elipandiana. Pascasio Radberto destaca la divinidad del Verbo desde todos los tiempos; su exinanitio, imprescindible para recibir la forma servi, exigencia de la Redención, se produce no para ser otro, sino para que el que es Dios sea hombre, in assumptione humanitatis. De su forma humana se deriva su condición primordial de speciosus, para que así no sea considerado no humano, pero, al tiempo, para que no se le pueda equiparar a un hombre del común.

Por otro lado, Pascasio Radberto propugna la unidad de Jesús-Cristo, de modo que no se afirme que Jesús no es el mismo que Cristo, que el Hijo de Dios no se escinda del Hijo del hombre. Totum eidem personae Deus Verbum est, totum ei homo Christus est, ... nec Christum aliud credere quam Jesum, nec Jesum alium praedicare, nec aliud quam Christum (Expositio in Psalmum XIJV, PL, CXX, esp. 1013ss).

En definitiva, un Verbo divino hecho hombre, pero no por ello disminuido, dos naturalezas indisociables, Jesús-Cristo. Las afirmaciones de Pascasio Radberto revelan la capacidad y el desarrollo teológicos en estas manifestaciones del reino astur.

58 Resulta muy evidente la procedencia hímnica de uernulus famulus o la teología subyacente al uerbum patris o la referencia apocaliptica del rex regum. 
Inmediatamente a la invocación sigue una referencia a la figura regia en donde se contrapone lo dicho con anterioridad. En efecto, frente a super omnia deus ..., se presenta un per omnia uernulus ... De este modo, el autor resalta el sometimiento regio a la voluntad divina. Actitud que se contrapondrá después con la jactantia de los reyes visigodos.

Tras esta primera parte vienen otras en las que destacan referencias a la teoría cristiana del poder. Se señala alí la autoridad divina sobre la realidad celeste y la terrestre; se subraya el lugat central de la justicia y el designio divino en la asignación de monarcas y leyes para establecerla. Se emplea el término distribuere para indicar este otorgamiento de reyes y leyes y, ciertamente, es el vocablo apropiado, pues la justicia no es sino la justa distribución (Etym., II, 24, 6).

En el Testamento también se acumulan imprecaciones al mediador y alusiones a los dones que se entregan y que esperan sean gratamente recibidos. Me interesa destacar algunas de las referencias. En el folio $4 r^{\circ}, 23$, aparece la mención del deus absconditus, tomada de Is., 45, 14. Terminología frecuente en las Escrituras y que fue desarrollada en la teologia de Agustín de Hipona.

Para Agustín, Dios es esencialmente invisible, es decir, la naturaleza divina de Dios es inasequible a los ojos del hombre. Sólo es accesible a la vista humana el hombre-Dios, el Dios encarnado ${ }^{59}$. Una propuesta antiadopcionista bien podría reforzar la invisibilidad del Hijo, para destacar así su verdadera filiación divina. Podemos relacionar esta invisibilidad divina con la ausencia de figuras en la pintura de Santullano, donde se representan temas arquitectónicos, pero no la figura humana. Además, podría coincidir este aniconismo con las propuestas del concilio de Frankfurt del 794 contra la adoración de las imágenes ${ }^{60}$.

Lo que puede decirse en cualquier caso es que las evoluciones religiosas del momento están en la misma línea que ciertas pautas tradicionales y las favorecieron. $\mathrm{La}$ idea agustiniana de que el Dios invisible gobierna el mundo desde un aula invisible ${ }^{61}$, pudo relacionarse con la expresión de un movimiento que reforzara la negatividad de las imágenes. Beato lo tecordaba en su Comentario al Apocalipsis. in Ecclesia non erunt idola (XII, 3, 47). La iglesia asturiana tampoco quedaba al margen de las decisiones que se estaban tomando en torno a la pretendida adoración oriental de las imágenes. Pautas tradicionales y, desde luego, una voluntad de no representar al Dios invisible y no llenar de ídolos la Jerusalem celeste ${ }^{62}$.

59 De Trin., II, 18.35; De civ. Dei, X, 12 y 13

60 Así se manifiesta J. Dodds, «Las pinturas de San Julián de los Prados», Goya, 191 (1986), esp. 260; en contra y señalando lo tradicional de esta pintura, I. Bango, «L'Ordo Gothorum et sa survivance dans I'Espagne du Haut Moyen Ages, Rémue de l'Ant, (1985), esp. p. 17. El asunto se complica con el problema general de la vinculación-procedencia de la arquitectura asturiana, desacreditado hoy su origen carolingio, también para Santullano (Bango, «De la atquitectura visigoda a la arquitectura asturianas, L'Europe héritière de l'Espagne wisigotbique, Madrid, 1992, 303ss; García de Castro, 460ss).

61 De Trin., III, 4.9.

62 El proyecto constructivo de Alfonso II recoge los elementos de una nueva Sión, la ciudad de David, muy propios de un ambiente apocalíptico. En ella se construyen dos conjuntos, el templo y el palacio, y también, como en el caso de Oviedo, se inaugura un nuevo reino perfecto.

Hipqunia, LVIII/3, núm. 200 (1998) 975-993 
Deus Srabel saluator. Beato se enfrentaba a judíos y adopcionistas a quienes comparaba por su negativa a considerar al crucificado Dios de Israel. Los adopcionistas alaban a Cristo, pero niegan que el clavado en la cruz sea el Dios de Israel (II, 42), pero Cristo es el Dios de Israel; el que está crucificado, el redentor y salvador, es verdaderamente Dios.

Hemos de pensar que este cúmulo de acciones, muchas de ellas innovadoras, debió formar parte de algún diseño general. En primer lugar, ya lo apuntábamos antes, estamos ante el primer rey astur ungido del que tenemos noticia. La unción no se produjo un domingo, frente a la práctica visigoda, sino el 14 de septiembre del 791, un miércoles. La fecha es recordada por la rotense, aunque no consta en la ovetense. Se corresponde con una fiesta muy especial en algunos calendarios, la de la Exaltatio Sanctae Crucis, es decir, la festividad dirigida a ensalzar la crucifixión. No es verosímil que el día se escogiera al azar, sino que hemos de pensar que se trató de una decisión sopesada.

Lo realmente extraordinario es que la festividad, ciertamente, no se corresponde con la tradición visigoda, pues en estos calendarios no figura la Exaltatio, celebrándose únicamente la Inventio, mientras que en el 14 de septiembre se conmemoraba a San Cipriano. Sin embargo, es una fiesta que está profusamente representada en los calendarios franco-romanos ${ }^{63}$. Diversas fuentes muestran que en Roma se celebraba una fiesta de adoración de la cruz el 14 de septiembre y que el papa Sergio I, según el Liber Pontificalis, había descubierto un relicario con la Vera $\mathrm{Cruz}^{64}$, celebrándose desde entonces aquel día en la basílica del Salvador, la realizada por Constantino (Letrán).

El asunto es de la mayor trascendencia si, como creemos, es un indicio de la presencia en el reino astur de influencias de todo tipo - también litúrgicasultrapirenaicas. Por otro lado, estas tendencias coinciden con el propio desarrollo de la polémica adopcionista, el alejamiento de la tradición visigoda y el anudamiento de lazos con los carolingios. Por supuesto, coincide con lo que ya sabíamos de la devoción a la cruz de la monarquía astur y del propio Alfonso II en particular. Es bien sabido que una magnífica cruz, la llamada Cruz de los ángeles, fue mandada hacer por el monarca en el 808. La cruz también puede hailarse en las pinturas de Santullano, ocupando lugares principales del templo.

Mas la crucifixión es propiamente el ámbito de la salvación, de modo que la devoción a la cruz nos remite de nuevo a la percepción de Jesucristo como Salvador. En la Exaltatio se incide en la divinidad del crucificado; es en la madera donde es crucificado Cristo, Dominus et Salvator, para la salvación de los hombres. La propia devoción a la cruz a la altura del 800 implicaba ciertas matizaciones que habrían de tomar partido ante la aún fresca contienda adopcionista.

63 FÁBREGA GraU, Pasionatio bispánico, Madrid-Barcelona, 1955, 209. C. Vogel, Introduction aux sources de l'bistoire du culte chrétien an Moyen Age, Spoleto, 1975. p. 55.

La Exaltatio en Liber Sacramentonum Gellonensir, ed. Dumas, Tumholt, 1981, 189s. En el gelasiano: Liber Sacramentorum Romande Aeclesiae ordinis anni cirnti, ed. Mohlberg, Roma, 1968, 158.

64 ANDRIEU, Les Ordines Romant du Haut Moyen Age, III, Lovaina, 1971, 504 y V, Lovaina, 1961, 363: In ipsa die salutant in palatio Lateranensi sanctam Crucem et sandalia domini. 
En definitiva, la data de la unción regia nos muestra la voluntad de Alfonso de poner su reinado bajo la dedicación de la cruz y de la verdadera salvación. Para ello había que recalcar la condición de Jesús-Cristo como verdadero Hijo de Dios. Como ya hemos visto, ha de entenderse esta polarización en la cruz como una muestra más de las tendencias antiadopcionistas del reino.

No obstante, el testimonio de Jonás de Orleans resulta decisivo para advertir la difusión en esos mismos años del adopcionismo en el reino astur. Como ya hemos apuntado Jonás sostiene la presencia de adopcionistas ya durante el reinado de Luis el Piadoso. En detalle, lo que sostiene Jonás es que en su juventud y gracias a su perspicacia fue capaz de advertir la pervivencia de adopcionistas, conclusión a la que llegó al juzgarlos secundum eorum actum et babitum, es decir, algunos componentes de sus prácticas religiosas y quizás de sus vestiduras no se correspondian con lo que Jonás consideraba ortodoxo. Es posible que simplemente estemos ante la pervivencia de la liturgia y de las tradiciones visigodas ${ }^{65}$.

En la Cruz de los ángeles y en el Testamento el rey astur se presenta como servus de la divinidad, precisamente la actitud contrapuesta a la achacada a los reyes godos, la praepotens jactantia. También en el Testamento el rey Pelayo y su sucesor reciben el apelativo de famulus. Este calificativo no es infrecuente en las inscripciones sepulcrales paleocristianas y en la liturgia, pero resulta novedoso en cuanto se aplica a los monarcas. En efecto, no parece haberse difundido su uso entre los reyes godos, aunque sí lo atestiguamos enseguida en el reino astur: Fávila recibe este apelativo en la inscripción de Cangas. Es preciso relacionar su empleo con prácticas cristianas, pero no conviene olvidar que Constantino el Grande constituye el referente básico, pues en repetidas ocasiones se presentó como famulus de la divinidad ${ }^{66}$.

El 16 de noviembre del 812 se ponia por escrito la donación a San Salvador de Oviedo. No es ésta la fecha de la consagración de la iglesia. Uría Ríu apuntó que se celebraba la dedicación de las iglesias el día 9 de noviembre y destacó que coincidía con la de la iglesia de Letrán erigida por Constantino también en ese día ${ }^{67}$. Es verosímil que, unos días después de la dedicación de las iglesias y sin desdeñar por completo la posibilidad de actos conjunto de la jerarquía eclesiástica con el rey, se produjera la donación.

El tema reviste gran importancia. $\mathrm{Ni}$ el día $16 \mathrm{ni}$ el 9 fueron domingo, es decir, ni la dedicación ni la dotación se llevaron a cabo en la fecha habitual para este tipo de acontecimientos. Tampoco se corresponde con un dia relevante en los calendarios hispánicos. Quizás otras razones llevaron a buscar este día. Algunos manuscritos presentan incluido en el Martyrologium una referencia a la dedicatio de la basilica lateranense ${ }^{68}$. No es anecdótica la coincidencia de fechas

65 Las prescripciones carolingias incluían la obligación del clero de llevar calzado a la romana (Duplex legationis edictum del 789 , c. 24).

66 Asi, por ejemplo, en la carta que dirige a los obispos reunidos en Arles. Comparte esta titulación con el clero.

67 "Cuestiones histórico arqueológicas ...», 288.

GB PL, XCIV, 1099s.

Hispania, LVIII/3, núm. 200 (1998) 971-993 
y la titulación de la iglesia: la etección de San Salvador de Oviedo seguía los pasos de la basílica romana y, claro es, el rey astur los del emperador cristiano, modelo evidente para la realeza cristiana. En última instancia, tanto el 14 de septiembre y el 9 de noviembre nos remiten a la devoción a la cruz y al emperador Constantino.

Las posibilidades modélicas de Constantino no habían tenido excesivo desarrollo en el reino visigodo tras Leovigildo y Recaredo. Los conflictos con el Imperio y la heterodoxia final de Constantino habían limitado en parte su capacidad. Sin embargo, el rey astur halla en él un precedente y ejemplo a seguir. También el emperador romano era devoto del Cristo Salvador, a quien había dedicado una basílica, construida en tierras de su propiedad y dotada espléndidamente, como atestigua el Liber Pontificalis. Se entiende ahora la incorporación de variantes del lema constantiniano a la Cruz de los ángeles (Hoc signo tuetur pius. Hoc signo vincitur inimicus). Se explica más aún el auge de la devoción a la cruz. No se trata de una cuestión aislada o marginal. Al contratio, forma parte de un todo, de un conjunto que busca adecuarse a las pautas de la monarquía cristiana, del emperador modélico.

De nuevo nos encontramos con indicaciones que no nos remiten al reino visigodo. La noticia de la dedicación de la basílica constantiniana no procede de los calendarios de tradición visigoda. Se trata posiblemente de referencias ligadas a la tradición romana, inmetsas también en esta liturgia, pero no en la hispana.

El tema creo que viene a comprobar lo que ya habíamos apuntado. En el reinado de Alfonso II hay una decidida actuación para anudar su reino a las tradiciones y prácticas religiosas ultrapirenaicas. Dicho de otra manera, no es en absoluto un momento recuperador de la tradición gótica. Lo que nos dice el Testamento, nuestra fuente más fiable, coincidiendo con todo lo que venimos analizando y destacando, es que el reinado de Alfonso no continúa nada. A la inversa, se da por acabada la historia de los godos y se combaten sus tradiciones. De hecho, se encuentra en otras coordenadas que le acercan al reino de los francos y también busca desarrollar su propia personalidad. Para ello se enfrenta a las tendencias adopcionistas de la Iglesia hispana, recibe en alguna proporción elementos litúrgicos de procedencia ultrapirenaica y busca en Constantino el ideal del monarca romano cristiano. Evidentemente, la política palatina no agotaba todo lo que se prodùcía en el reino y, así, Jonás podía encontrar a quienes le parecian adopcionistas, pero también a quienes no lo eran. Es decir, podía estar ante prácticas diversas, unas de tradición visigoda y otras no tanto.

En definitiva, estas perspectivas nos revelan un reino astur muy distante de la mera continuación del visigodo. Alfonso II testimonia una voluntad de alejamiento de esa tradición y una búsqueda de otras referencias religiosas y políticas. Sus contactos con los carolingios están indicando todas estas realidades y contradicen la imagen de un reino visigodo resistente en las montañas asturianas. 